\title{
INTRODUCTION: THE MANY CULTURES OF WALT WHITMAN, PART TWO
}

ThIS DOUBLE ISSUE of the Walt Whitman Quarterly Review comprises the second part of a collection of essays representative of the conference, "The Many Cultures of Walt Whitman," held at Rutgers, the State University of New Jersey, in Camden on October 23-25, 1998. The conference explored the connections between Whitman's works and the cultural forces that the poet drew on, as well as the effects of his work on related and later cultural products.

The first essay in this part resumes a discussion that concluded the first part-Paul Benton's suggestion that a "conversion narrative" lay submerged below Whitman's prose notes on a procession of prisoners he observed during the Civil War. Here, Maire Mullins finds a similarly submerged narrative in Whitman's poetry about the war, though the narrative tells a different story. "Stopping History in Walt Whitman's 'Drum-Taps'” argues that Whitman often freezes historical time in order to tell another story of affection and love between men. Whitman injects a tableau, catalog, or scene into many poems that is separate from the main action or flow of ideas; this inserted moment of stopped time tells the second narrative of homoerotic desire and loving comradeship so crucial to Whitman's experience of war.

Concerned that the war had made existence unreal or illusory, latenineteenth-century writers and thinkers embarked on a quest for "authenticity." Mary McAleer Balkun, in her essay "Whitman's Specimen Days and the Culture of Authenticity," explains how Whitman's text both anticipates and demonstrates this cultural preoccupation. Interested not so much in rendering the surface reality of his subject as in capturing the emotional quality of experience, Whitman sought in Specimen Days suitable forms of expression to create "genuine facsimiles" of reality.

Authenticity is also an issue in "The Poet-Chief Greets the Sioux," in which Martin G. Murray describes the "poet-chief"s" encounter with a Sioux delegation to Washington, D.C., in 1872. He establishes the provenance of Whitman's prose piece, "Real American Red Men," and explores Whitman's personal, political, and professional reasons for writing this piece of journalism. Contrary to expectation, Whitman undercuts the philosophical foundation of Grant's Indian policy by cel- 
ebrating the value and dignity of Indian culture. He also asserts his own authority as "poet-chief," thus promoting his own cause as well as that of the Sioux.

The authority and authenticity of Whitman's voice are also at stake in his representations of the body. Though Whitman was famous for his poems about the body written early in his career, his later poems, with their representations of bodily suffering, have received comparatively little attention. Benjamin Lee's "Whitman's Aging Body" begins to fill that gap, as he takes up Whitman's difficulties in giving voice to the pains of old age, which seem inconsistent with his successes in imagining bodily presence in the 1850s and 1860s. Drawing on theorist Elaine Scarry's notion of pain's inexpressibility, Lee shows how Whitman's aesthetic shifts accord with his changes in physical condition, his growing sense of the difficulty of describing his own pain. Specifically, he argues that the figure of metonymy - so integral a part of Whitman's early poetry - finally yields to the figure of metaphor, as the "wreck'd" body is no longer able to come into sympathetic and sensual contact with others.

While Whitman's fascination with music, especially opera, has been carefully documented, musicians' love of Whitman and his poetry is less well known. Caryn Block's "The Sounds of Whitman: A Composer's View" examines musical settings of Whitman's work by three twentieth-century American composers-Ned Rorem, Vincent Persichetti, and Roger Sessions. Her discussion of the translation of Whitman's verbal art into musical image highlights the complex negotiations that go on between artists working in different media and separated by time, illustrated by her own setting of two of Whitman's lyric poems.

Much has been made of the importance of Whitman's incorporation into his poetry of contemporaneous philosophical theories. In "Walt Whitman and the Culture of Pragmatism," Daniel Malachuk documents the incorporation of Whitman's poetry into the philosophy of pragmatism, notably that of William James. Pointing out the ways in which Whitman's poetry was used by James both to persuade others to be pragmatists and to bolster his own education into it, Malachuk shows that James's pragmatist conceptions, in particular his notion of a pluralistic universe, find support and expression in Whitman's optimistic view of the possibilities of the self. His essay ends by tracing the continuing influence of Whitman's work in late twentieth-century pragmatism, particularly in the writings of Richard Rorty.

Another way in which Whitman is present in modern culture is demonstrated in Desirée Henderson's essay, "Dr. Quinn, Medicine Woman and the Prime-time 'Outing' of Walt Whitman." Henderson analyzes Whitman's controversial sexuality as the object of spectacular consumption in this popular television program set in Colorado in the 1870 s. When the revered visiting poet is joined by his lover, Peter Doyle, 
the town struggles to reconcile Whitman's official and scandalous identities. Henderson concludes that the episode enacts in structure, characterization, and dialogue the problems of a society that professes the value of difference but fails to find a place in which it can reside or flourish.

In these two double issues, we have been able to include only a fraction of the papers that were presented, and thus to represent only a few of the connections that were made at the conference between Whitman and his many cultures. Nevertheless, the essays in this collection demonstrate the theme of the conference-the multiplicity of ways in which Whitman's writings express the values, contradictions, and successes of both high and low culture of the United States from the 1840s to the 1890s. In his poems and prose, he responded to and helped to shape the discourses of urban expansion and immigration; of slavery, abolition, and the Civil War; of social and political reform; of scientific and technological discovery; of print and performance culture; of literary romanticism and realism. Whitman participated broadly in the ideas and events of his time, and his works continue to exert influence on American culture today.

Rutgers University, Camden

TyLER HoFFMaN GeOFFrEy SILL Carol J. Singley 